\title{
MODERN APPROACHES TO QUALITY EVALUATION OF ENZYME-LINKED IMMUNOASSAY DIAGNOSTIC KITS
}

\author{
V.M. Shchetinin* \\ Weston Foods Inc., Winnipeg, Canada \\ *Corresponding author: Valeria.shchetinin@westonfoods.com \\ Received 22 December 2019; Accepted 28 January 2020
}

\begin{abstract}
Background. Enzyme-linked immunoassay (ELISA) diagnostic kits are a medical device designed to solve an important task as patient's life and health depend on the correctness of laboratory test result. Therefore, at present, special attention is given to the quality of in vitro diagnostic medical devices, which in turn is related to standardization and technical regulation.

Objective. The goal of the work was analysis of up-to-date methodological approaches to quality assessment of ELISA diagnostic kits.

Methods. The results of the development, standardization, and testing of ELISA kits, as well as the recommendations of international institutions and certification bodies, were studied and analyzed.

Results. Properties of biological components of diagnostic kits (immunoenzymatic conjugates and immunosorbents) were analyzed; their impact on diagnostic quality level of ELISA kits was determined. The current methodology for assessing the quality conjugates and immunoassay diagnostic kits, in general, was analyzed. The important role of standardized sera panels (qualification, verification, seroconversion, expert, and sensitivity panels) in the assessment procedure for the diagnostic ELISA kits has been demonstrated. The methods of obtaining control materials used to assess the quality of diagnostic kits were analyzed. Special attention was paid to methods to ensure the stability of control materials.

Conclusions. In the case of the most socially important infections (HIV, hepatitis B and C), strict values of specificity and sensitivity have been established by regulatory authorities and/or international institutions. In the case of other diseases, rationing of diagnostic indicators has to be performed (justified) by research and development group and/or by the manufacturer.
\end{abstract}

Keywords: ELISA kits; diagnostic quality; sera panels; control materials.

\section{Introduction}

Laboratory diagnostics is an integral part of patient's clinical examination, as the lack of laboratory examination data prevents not only establishment of clinical diagnosis, but also the control of efficacy and safety of therapeutic measures. An important place among the whole complex of clinical laboratory diagnostic methods belongs to serological methods, which are based on identification of serological markers (antigens, allergens, antibodies) of infectious and non-infectious diseases. Enzymelinked immunoassay (ELISA) is the most informative, multipurpose (such that can be used for diagnostics of a pathological condition by the way of identification of one or another biological marker using "antigen-antibody" reaction) and, as a consequence, widespread method among serological studies [1].
Enzyme-linked immunoassay diagnostic kits (ELISA kits) are a specific type of products belonging to the class of medical devices. It's obvious that the task solved by such diagnostic kits is extremely responsible, as patient's life and health depend on the correctness of laboratory test result. That is why, at modern step, quality issues of medical devices for in vitro diagnostics enjoy special attention [2]. Scientific justification of bioanalytical standardization parameters of medical devices for serological in vitro diagnostics, including ELISA kits, have been carried out in a series of works [2-4]. Evaluation of requirements of international normative documents on quality and safety of in vitro diagnostic devices enables the formulation of general recommendations on ELISA kits quality management at development, testing, and manufacturing steps. The goal of this work was analysis of up-to-date methodological approaches to quality assessment of enzyme-linked immunoassay diagnostic kits. 


\section{Diagnostic quality of biocomponents of diagnostic kits}

Monoclonal antibodies (McAbs) are used in ELISA kits in two forms: as a part of immunosorbent or in the form of conjugate with an enzyme (most frequently peroxidase). Modern diagnostic kits include McAbs-based conjugates, specific to various infectious and non-infectious antigens [5-7].

Quality of ELISA kits mainly depends on its two components: immunosorbent and immunoassay conjugate. The one of the ways to improve the parameters of diagnostic kits is improvement of immunoassay conjugates. In relation to this, certain criteria on which diagnostic characteristics of conjugates are dependent should be formulated. First, a conjugate quality is dependent on its ingredients [8]. In the case of McAbs conjugates, their qualitative parameters are dependent, on the one hand, on specificity, sensitivity, affinity, stability, and purity of antibodies; on the other hand, they depend on the activity, stability, and purity of an enzyme. Second, the quality of conjugate is directly affected by its production method. In this case, the following "weak points" are worth attention. Reagents used for conjugation have to exert minimal effect on the activity of antibodies and enzyme. The control of presence of non-bound immunoglobulin molecules in synthesized conjugate is also essential, as their presence inevitably results in decrease of conjugate sensitivity. Non-bound enzyme in conjugate composition can cause an adverse increase of background signals $[9,10]$. Third, the ratio between enzyme and antibodies in the conjugate is of utmost importance. Conjugates with different antibodies:enzyme molar ratio are used in different test kits (depending on the specificity of the formed immune complex) [11-13]. E.g., in order to overcome the effect of high HBsantigen doses upon its identification in blood sera in "sandwich" ELISA variant, the following McAbs conjugates with polymer peroxidase are used: up to 10 peroxidase molecules per 1 immunoglobulin molecule [14]. At the same time, the molar ratio between enzyme and antibodies of about 1:2 is applied for production of antispecies conjugates used in test kits for detection of antibodies against various causative agents in indirect ELISA [12]. Fourth, diagnostic quality of conjugates is intimately related to their stability. Conjugate stability is almost the only factor limiting a diagnostic kit shelf life [15]. That is why multicomponent stabilizing solutions typically containing albumin, oligosaccharides, phenol derivatives, inorganic salts, etc. are used for preservation of conjugates.

Thus, several factors affect the quality of immunoassay conjugate. Nevertheless, even at all similar conditions of production of conjugates from various McAbs their parameters when used in test systems will be different. That is why a wide range of relevant McAbs has to be available for development for any enzyme-linked immunoassay kit: only one or a few conjugates from the whole antibody panel show satisfactory results in a specific test kit [13].

\section{Methodology for quality assessment of immuno- assay conjugates and diagnostic kits}

Testing of immunoassay conjugates in the formulation of diagnostic kits is carried out in several steps; nevertheless, this process is impossible without the use of one or other reference materials. Development and manufacture of standards, calibrators, and reference materials for clinical laboratory studies is an essential branch of activity of large manufacturers and research centers. Requirements and recommendations for the manufacture, attestation, and implementation of international biological standards are contained in normative documents, which are being regularly issued by the Committee on Standardization of the World Health Organization (WHO) [16, 17].

Depending on the purpose, reference materials of biological origin can be manufactured in the form of standards, represented by a limited number of nonrenewable aliquots, or in the form of panels of reference sera, which are regularly manufactured on an industrial scale. An immunobiological standard manufactured on the basis of human blood serum is a sample of reference serum possessing quantitatively characterized activity expressed in international units, measured by a certain method [16-18].

For quality assessment of immunoassay conjugates, quality of production batches of diagnostic reagent kits, intralaboratory quality control, and clinical efficacy of the method as such, individual reference materials can be combined into reference material panels. The following main types of reference material panels are classified [16-19].

Qualification panel comprises serum samples representing reactivity variants, which can rarely be encountered in routine testing (different genotypes, subtypes, clinical variants, etc.). Such panels are used 
for training, testing staff performance, identification of systematic errors and malfunction of equipment, as well as violations in the method execution within the scope of overall quality control system. The test result is represented in yes/no form. This panel can include either diluted or non-diluted serum samples.

Verification panel is a panel of natural non-diluted serum samples with different titers. The panels are intended for use as reference reagents with nonestablished precision. They are used for precision assessment and monitoring of commercial kits usage system. These panels can not replace the reference samples in the composition of test systems. The panels are recommended for establishment of confidence interval during validation of test systems. Such panels can include sera with low and/or high specific antibody titers.

Seroconversion panel includes blood serum samples from one patient, taken at little time intervals, which characterize individual dynamics of the marker.

Expert panel includes natural non-diluted samples of blood serum and plasma, containing a certain marker, completely characterized in reference laboratory via methods officially permitted for use, using certified test systems. The panel is accompanied by a table showing the testing data of sera in its composition obtained using commercial test systems. Such panels are intended for establishment of analytical sensitivity at routine external assessment of work of a laboratory.

Sensitivity panel is intended for quantitative assessment of sensitivity of various tests. It contains several consecutively diluted tests. It is calibrated against international standards.

Primary characterization is performed at assessment serum panel; in-house panel (IHP) of a certain manufacturer is typically used as such (by formation method, such panels are usually classified as qualification or verification panels) [20, 21].

It's customary to evaluate the test results by the value of positivity factor - the ratio between optical density (OD) of positive blood sera $\left(\mathrm{OD}_{\text {ser }}^{+}\right)$and the cut-off value $(\mathrm{COV}) . \mathrm{COV}$, in its turn, is measured as follows:

$$
\mathrm{COV}=\mathrm{OD}_{\mathrm{ser}}^{-}+3 \sigma,
$$

where $\mathrm{OD}_{\text {ser }}$ is the value of mean optical density of negative samples; $\sigma$ is mean square deviation of OD values of negative sera [3, 4].
Further characterization (measurements of sensitivity and specificity parameters) is carried out for conjugates showing the best results upon testing on IHP sera.

The key quality parameters of immunoassay conjugates and other biocomponents of the diagnostic kit, determining quality of the latter, are sensitivity and specificity.

Sensitivity is known as a parameter characterizing a test kit ability to identify the maximum number of truly positive sera. Sensitivity reflects the percentage of infected individuals, who can be identified using this test kit [21].

Determining the sensitivity of test systems, in accordance with recommendations by WHO, CDC (Centers for Disease Control and Prevention), FDA (US Food and Drug Administration), is made by assessment of diagnostic kits capability to identify positive sera of standard reference panels [20]. The Table shows the requirements for sensitivity testing of screening test kits, intended for identification of serological markers of HIV, viral hepatitis B and C, established by the Paul-Ehrlich-Institut of the German Federal Ministry of Health to serological diagnostics agents submitted for registration (certification) $[22,23]$.

Another quality parameter of a diagnostic kit, specificity, characterizes a test kit capability to identify only the component for which it is intended, i.e. characterizes a diagnosticum ability to register a minimal number of false-positive sera [20].

Test systems specificity measurement is performed using a wide range of negative sera characterized in other test systems or using other conjugates.

In accordance with recommendations of WHO experts, sensitivity and specificity parameters of diagnostic preparations have to meet the minimum requirements - not less than $99 \%$ and $95 \%$, respectively (HIV testing) [20]. In case of diagnostics of other infections or identification (measurement) of other biological analytes, these parameters have to be scientifically justified $[24,26]$.

Studies for determination of test sensitivity and specificity parameters, as well as determining the stability of conjugates and other biocomponents upon long-term storage (including testing after short-term exposure to stress factors, first of all, temperature factor), should be carried out in order to evaluate suitability of immunoassay conjugates for use in test systems [1]. 
Table: Sensitivity requirements of screening test kits intended for identification of serological markers of HIV, viral hepatitis B and C [22, 23]

\begin{tabular}{|c|c|c|c|c|}
\hline Tested marker & Seroconversion sensitivity & Diagnostic sensitivity & Analytical sensitivity & Genotype, subtype, mutant differences \\
\hline Anti-HIV-1/2 Ab & \multirow{4}{*}{$\begin{array}{l}\text { For all HIV, HCV and HBsAg } \\
\text { screening tests, the sensitivity } \\
\text { must be determined during the } \\
\text { early infection phase (serocon- } \\
\text { version) by testing } 30 \text { serocon- } \\
\text { version panels with short inter- } \\
\text { vals between the blood collec- } \\
\text { tions in the range in which the } \\
\text { seroconversion takes place in } \\
\text { comparison with a CE marked } \\
\text { test kits }\end{array}$} & \multirow{3}{*}{$\begin{array}{l}\text { Diagnostic sensitivity has to be tested in } \\
400 \text { positive samples, and, for HIV tests, } \\
\text { additionally in } 100 \text { anti-HIV-2 positive } \\
\text { samples at different stages of the disease. } \\
\text { The test has to show positive result for all } \\
\text { samples which were confirmed as positive via } \\
\text { Western blotting or linear immunoassay. } \\
\text { The parameter of diagnostic sensitivity, } \\
\text { checked on commercial standard panels of } \\
\text { blood serum (plasma), should be } 100 \%\end{array}$} & Not applicable & $\begin{array}{l}\text { Sensitivity for HIV-1 subtype group M } \\
\text { comparable with subtype B For HIV-1 } \\
\text { group } 0 \text { and for HIV-2, the test must be } \\
\text { positive at least for samples serologically } \\
\text { confirmed as positive }\end{array}$ \\
\hline $\mathrm{HIV} \mathrm{Ag/Ab}$ & & & $\begin{array}{l}\text { HIV-1 p24 antigen: } \\
\leq 2 \mathrm{IU} / \mathrm{ml}(\mathrm{WHO} \\
\text { standard } 90 / 636)\end{array}$ & $\begin{array}{l}\text { Sensitivity for HIV-1 p } 24 \mathrm{Ag} \text { of subtype } \\
\text { group M comparable with subtype B. } \\
\text { Reactivity for HIV-1 group } 0 \text { must be } \\
\text { present. Proof must be provided for de- } \\
\text { tection of HIV-2 }\end{array}$ \\
\hline $\begin{array}{l}\text { Anti-HCV Ab, } \\
\mathrm{HCV} \mathrm{Ag/Ab}\end{array}$ & & & Not applicable & Identification of HCV genotypes 1-6 \\
\hline HBsAg & & $\begin{array}{l}\text { For HBsAg, the test has to show the efficacy } \\
\text { of function in accordance with the state of } \\
\text { the art }\end{array}$ & $\begin{array}{l}<0.1 \mathrm{IU} / \mathrm{ml}(\mathrm{WHO} \\
\text { standard } 00 / 588)\end{array}$ & $\begin{array}{l}\text { Sensitivity of HCV genotypes and/or } \\
\text { HBsAg subtypes has to be comparable } \\
\text { to genotype A. Identification of known } \\
\text { mutants of HBsAg }\end{array}$ \\
\hline Anti-HBc Ab & $\begin{array}{l}\text { Testing of } 10 \text { seroconversion } \\
\text { panels minimum with an Anti- } \\
\text { HBc Ab course. The sensitivity } \\
\text { has to meet the governmental } \\
\text { requirements }\end{array}$ & $\begin{array}{l}\text { Diagnostic sensitivity has to be tested on } \\
400 \text { positive samples. } \\
\text { All samples which are simultaneously positive } \\
\text { for anti-HBe } \mathrm{Ab} \text { and/or anti- } \mathrm{HBs} \mathrm{Ab} \text {, must } \\
\text { be recognized ( } 100 \% \text { sensitivity). } \\
\text { Isolated anti-HBc Ab positive samples must } \\
\text { be examined comparatively for clarification } \\
\text { using at least } 2 \text { additional anti-HBc Ab tests }\end{array}$ & $\begin{array}{l}<1.40 \mathrm{IU} / \mathrm{ml}(\mathrm{WHO} \\
\text { standard 95/522) }\end{array}$ & Not applicable \\
\hline
\end{tabular}

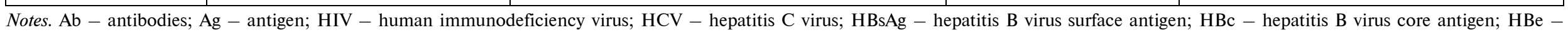
hepatitis B virus e-antigen; IU - international units; CE - European Conformity marking. 


\section{Reference materials used for diagnostic kits quality assessment}

In accordance with international recommendations, preference in development of reference materials is currently given to non-diluted human blood sera in liquid (native) form, as they, according to their biological properties, are closest to the samples used for diagnostic studies in clinical laboratories $[18,27]$.

As a rule, non-diluted blood serum samples [18, 27-29], as well as defibrinated blood plasma [30], obtained from patients with clinically established diagnosis, are used as starting raw materials in the manufacture of reference materials for diagnostics of various infections. In this case, the activity degree of antibodies (or antigens) contained in reference materials has to be within the range of values enabling to take a diagnostic decision [27, 31].

The necessary prerequisite of creation of biological standards and reference materials is assurance of their stability, i.e. ability to preserve their specific characteristics (antibody activity level) upon storage for a long time (not less than 1-2 years) [16$18,24-26]$.

Stability of reference materials is affected by quality of raw materials used for their manufacture. Compliance with several requirements aimed at maintenance of initial specific activity, homogeneity, and other physicochemical and biological properties of raw material is needed during production of reference materials [16, 32]. Raw materials during their production processing have to be kept in controlled conditions, preventing potential negative impact on them via enzymatic activity, air oxygen, light, and changes in storage temperature regimen [18]. Adverse effects on conformational structure of blood serum protein molecules can be exerted even by routine technological procedures, such as pumping with plunger pump or abrupt shaking [33].

Several methodological techniques are known which allow assuring long-term preservation of specific antibody activity in native serum material samples (stability); they provide for the use of additional factors of physical or chemical impact (freeze-drying, addition of preservatives and stabilizers, sterilization filtration, freezing, etc.) [16-18, 28, 30, 33].

Among factors of physical nature, first of all, stabilizing effect of low temperature should be mentioned. Blood sera can maintain antibodies activity at temperature $2-10{ }^{\circ} \mathrm{C}$ for a long time provided they are sterile (or provided antimicrobial substances are added to them). Many scientists noticed abrupt deceleration in protein structures degradation dynamics upon fast freezing of protein solutions and their further storage in low-temperature conditions [16, 34]. Deeper freezing of reference materials, e.g. at $-70^{\circ} \mathrm{C}$, assures much more reliable and reproducible result of maintenance of antibodies specific activity in reference sera [16-18]. It is obvious that the above approach can hardly be implemented for practical use in clinical laboratories of health care facilities. Finished product delivery conditions from a manufacturer to a customer do not allow maintaining temperature regimen necessary for preservation of initial activity of reference materials in all links of cold transport chain.

Development of freeze-drying technology has become one of scientific achievements of the 20th century, which was widely used for long-term (25 years and more) storage of medical immunobiological products, including blood products and their derivatives [18]. Nevertheless, reference materials in lyophilized form, despite transportation and storage convenience, have shown certain limitations upon their further use. During lyophilization, blood serum was subject to complex technological processing and dehydration, in the process of which partially irreversible changes of spatial conformational protein structure took place. These changes were related to formation of stable oligo- and monomeric isoforms or covalent aggregates, which were essentially different from the starting native form [35-37]. A part of specific antibodies is denaturated even after a single freezing, and limitations related to the use of lyophilized reference materials for control of serological diagnostics methods become obvious [18]. Besides, there is a high probability of errors during handling of lyophilized reference materials related with their loss on drying and/or careless vial opening, as well as during their reconstitution in liquid form (diluent metering errors, non-compliance with time required for conformational changes and stabilization of proteins in solution, stirring quality) $[18,38]$. Each of the named factors can potentially result in situation when the reference material samples produced from the same vial or vials of the same batch are essentially different by immune antibodies content from the one specified by the reference material manufacturer. Besides, reference materials obtainned from lyophilized sera have elevated turbidity or opalescence [36, 39], which places an additional limit on their use in several serological tests [18, $31,39,40]$.

In accordance with international recommendations [16, 17], the optimal sets of immunobiological 
reference materials for laboratory tests are panels of reference sera including samples containing or not containing antibodies against the tested pathogen. In this case, the manufacture of reference materials from human blood serum in liquid native form prevents the occurrence of measurement errors caused by preparatory procedures related to the reconstitution of lyophilized reference sera.

A possible methodological approach to the solving the problem of preservation of immune antibodies specific activity in reference materials produced on the basis of human blood serum matrix is the use of high molecular natural or synthetic compounds and surface-active substances, which bind immunoglobulin molecules electrostatically due to their hydrophobic nature, via non-covalent bonds, forming stable complexes [18].

Chemical reagents used as preservatives should not affect specific activity of sera and prevent the testing. Various reagents are used as preservatives, for example, boric acid and salts thereof, different antibacterials, sodium azide [41], merthiolate, ethylene glycol [28], ethylenediaminetetraacetate (EDTA) [42]. It should be mentioned that the use of sodium azide has certain limitations, as this reagent possesses inhibitory activity against the enzyme horseradish peroxidase, included in the formulation of virtually all enzyme-linked immunoassay reagent kits [18].

Various carbohydrates and biopolymers are frequently added as stabilizers upon freezing of protein solutions and their further lyophilization [43-45]. Studies [46] have shown that addition of distilled water to lyophilized bovine serum albumin results in complete restoration of native spatial structure of protein molecules - refolding only in the presence of sugars (sucrose, trehalose, or dextrans); such restoration did not occur in samples without sugar addition. The most widespread stabilizer of carbohydrate origin is sucrose; nevertheless, available data confirm that another disaccharide, trehalose, possesses the best stabilizing properties [45]. Positive effect of certain sugars on maintenance of protein structures contained in preparation solutions was also mentioned in other studies [46]; nevertheless, preference in them was given to di- and oligosaccharides, as larger carbohydrates are capable to form aldehydes [47].

Blood plasma and serum proteins in the process of long-term storage in non-frozen form can undergo degradation due to the presence of enzymes possessing proteolytic activity [48]. Assurance of long-term preservation of reference materials having specific immune activity requires the development of stabilizing additives capable to inhibit proteolytic effects of blood serum enzymes. Such stabilizing additives can include inhibitors of proteolytic enzymes - antitrypsins, in particular, $\alpha_{1}$-antitrypsin, a glycoprotein synthesized by liver and inhibiting activity of many proteolytic enzymes: trypsin, chymotrypsin, plasmin, thrombin, elastase, hyaluronidase, leukocyte proteases [18].

Ingredients possessing pronounced antibacterial and antifungal activity are widely used for prevention of bacterial contamination of reference materials. Preservation by the sterilization filtration and further storage at temperatures of 2 to $8{ }^{\circ} \mathrm{C}$ is used for the same purpose [28]. In US Centers for Disease Control and Prevention, final processing of serum material during preparation of reference materials and reference samples for qualification testing in serological laboratories is performed by the way of two-step filtration: first, through a $0.45 \mu \mathrm{m}$ filter, and, subsequently, through a $0.22 \mu \mathrm{m}$ filter [27].

\section{Conclusions}

Thus, we analyzed literature data regarding the properties of biological components of diagnostic kits and their impact on diagnostic quality level of kits in total. Particular attention was paid to the current methodology for assessing the quality conjugates and immunoassay diagnostic kits in general. It was underlined role of standardized sera panels (qualification, verification, seroconversion, expert, and sensitivity panels) in the assessment procedure for the diagnostic ELISA kits. As evidenced by the available data in the case of the most socially important infections (HIV, hepatitis B and $\mathrm{C}$ ), strict values of specificity and sensitivity have been established by regulatory authorities and/or international institutions. In the case of other diseases, rationing of diagnostic indicators has to be performed (justified) by research and development group and/or by the manufacturer. Finally, we analyzed the methods of obtaining control materials used to assess the quality of diagnostic kits.

\section{References}

[1] Galkin OY, Komar AG, Pys'menna MO. Specificity of manifacturing process validation for diagnostic serological devices. Biotechnologia Acta. 2018;11(1):25-38. DOI: 10.15407/biotech11.01.025

[2] Galkin OY, Komar AG, Grygorenko AA. Bioanalytical standardization of medical devices for serological diagnosis. Biotechnologia Acta. 2015;8(2):112-9. 
[3] Lutsenko TN, Kovalenko MV, Galkin OY. Validation of biological activity testing procedure of recombinant human interleukin-7. Ukr Biochem J. 2017;89(1):82-9. DOI: 10.15407/ubj89.01.082

[4] Galkin AY, Dugan AM. Elaboration of immunoenzymatic test-kit for total human IgE assay and investigation of its analytical properties. Int J Immunol. 2013;1(1):1-6.

[5] Kabernyuk AA, Oliynyk OS, Redchuk TA, Romanyuk SI, Kolibo DV, Yevtushenko VV, et al. Development of immunochemical test systems for the control of anti-diphtheria immunity in people population. Sci Innov. 2008;4(3):22-31.

[6] Siromolot AA, Redchuk TA, Solodiankin OS, Kolibo DV, Gerilovich AP, Komisarenko SV. The trial of experimental test system for the specific diagnostics of cattle tuberculosis. Biotechnologia Acta. 2016;9(4):14-8. DOI: 10.15407/biotech9.04.014

[7] Galkin OY, Besarab AB, Lutsenko TN. Characteristics of enzyme-linked immunosorbent assay for detection of IgG antibodies specific to Chlamydia trachomatis heat shock protein (HSP-60). Ukr Biochem J. 2017;89(1):22-30. DOI: 10.15407/ubj89.01.022

[8] Linghu X, Segraves NL, Abramovich I, Wong N, Müller B, Neubauer N, et al. Highly efficient synthesis of a Staphylococcus aureus targeting payload to enable the first antibody-antibiotic conjugate. Chemistry - A European Journal. 2018;24(12):2792. DOI: $10.1002 /$ chem. 201706013

[9] Golub N, Levtun I. Impact of sound irradiation on Chlorella vulgaris cell metabolism. Eastern-European J Enterprise Technol. 2016;2(10):27-31. DOI: 10.15587/1729-4061.2016.63730

[10] Saegerman C, De Waele L, Gilson D, Godfroid J, Thiange P, Michel P, et al. Evaluation of three serum i-ELISAs using monoclonal antibodies and protein $\mathrm{G}$ as peroxidase conjugate for the diagnosis of bovine brucellosis. Vet Microbiol. 2004;100(12):91-105. DOI: $10.15587 / 1729-4061.2016 .63730$

[11] Hermanson GT. Bioconjugate techniques. 3rd ed. San Diego: Academic Press; 2013.

[12] Oh JG, Seong J, Han S, Heo TH. Development of an anti-EPO antibody detection kit based on lab-on-a-chip and bridging antibody technologies. Biologicals. 2018;54:8-12. DOI: 10.1016/j.biologicals.2018.05.005

[13] Nikolaenko IV, Galkin AY, Raevskaya GE, Kas'ianenko TV, Nereshchenko MI, Donskaia ES, et al. Preparation of monoclonal antibodies to the Fc-fragment of human IgG and the use of their based immunoenzyme conjugates. Clin Lab Diagn. 2005;11:8-11.

[14] Donskaya ES, Raevskaya GE, Nikolaenko IV. The use of conjugate of monoclonal antibodies with polymer peroxidase as a way to increase the sensitivity and reduce the hook effect of high doses in ELISA for the determination of HBsAg. Viral hepatitis B diagnosis, treatment and prevention. In: Proc. Rus Sci Conf; 2004; Moscow. p. 49-50.

[15] Semynozhenko VP, Moskalenko VF, Hural AL, editors. HIV/AIDS: problems of etiology, epidemiology and diagnosis. Kyiv: Poligraf Express; 2004.

[16] WHO. Recommendations for the preparation, characterization and estab-lishment of international and other biological reference standards. WHO Technical Report Series. 2004.

[17] In vitro diagnostic medical devices - Measurement of quantities in samples of biological origin, description of reference materials. ISO 15194:2009.

[18] Cauchard J, Soldan A, Madeline A, Johnson P, Büscher P, Petry S. Inter-laboratory ring trials to evaluate serological methods for dourine diagnosis. Vet. Parasitol. 2014;205(1-2):70-6. DOI: 10.1016/j.vetpar.2014.06.025

[19] Kubanova AA, Frigo NV, Rotanov SV. System of external and internal quality control of laboratory diagnosis of sexually transmitted diseases in the Russian Federation. Moscow: TsNIKVI; 2006.

[20] National HIV testing day and new testing recommendations. MMWR Morbidity and Mortality Weekly Report. 2014;63(25):537. DOI: $10.15585 / \mathrm{mmw} . \mathrm{mm} 6825 \mathrm{a} 1$

[21] Galkin OY. Approaches to the synthesis of conjugates for enzyme immunoassay test-systems and evaluation of their use for diagnostics of infectious diseases. Ukr J Clin Lab Med. 2010;5(4):54-60.

[22] The official website of the Institute Paul Ehrlich behalf of the Federal Ministry of Health of Germany [Internet]. 2019 [cited 2019 Dec 14]. Available from: http://www.pei.de/SharedDocs/Downloads/EN/blood-components/donor-screening/peirequirements-screening-ivd.pdf?_blob=publicationFile \&v $=2$

[23] Commission decision of 27 November 2009 on common technical specifications for in vitro diagnostic medical devices (2009/886/EC). Official Journal of the European Union. 2009;L318:25-40.

[24] Parreno V, Romera SA, Makek L, Rodriguez D, Malacari D, Maidana S, et al. Validation of an indirect ELISA to detect antibodies against BoHV-1 in bovine and guinea-pig serum samples using ISO/IEC 17025 standards. J Virol Meth. 2010;169(1):143-53. DOI: 10.1016/j.jviromet.2010.07.014

[25] Ederveen JC. A practical approach to biological assay validation. Hoofddorp: Progress; 2010.

[26] Schultheiss OC, Stanton SJ. Assessment of salivary hormones. Methods in Social Neuroscience. New York: Guilford Press; 2009.

[27] Ricos C, Juvany R, Simon M, Hernández A, Alvarez V, Jiménez CV, et al. Commutability and traceability: their repercussions on analytical bias and inaccuracy. Clin Chim Acta. 1999;280(1-2):135-45. DOI: 10.1016/s0009-8981(98)00187-9 
[28] Hu M, Liu N, Cai YY, Lei T, Zhang M. Accuracy analysis and comparison of different serological detection methods in syphilis. Zhonghua Yi Xue Za Zhi. 2017;97(36):2844-7.

[29] Ivchenko SN, Susloparov IM, Masyicheva VI. Construction of a liquid panel of sera containing and not containing antibodies of IgG class to human cytomegalovirus. Vestnik RAMN. 2004;8:37-40.

[30] Castro AR, Kikkert SE, Fears MB, Pope V. Defibrination of blood plasma for use in serological tests for syphilis. Clin Diagn Lab Immunol. 2002;9(6):1376-8. DOI: 10.1128/cdli.9.6.1376-1378.2002

[31] Kanev AN, Vorobeva MS, Shalunova NV. Development of standard serum panels for quality control of immunoenzyme test systems in Russia. Vestnik RAMN. 1998;3:47-51.

[32] Jeffcoate SL. WHO guidelines for the preparation of international standards and other reference materials for biological substances. Dev Biol Stand. 1992;74:195-201.

[33] Pankratov O, Shimanskaya I, Pankratov V, Navrotsky A, Ballard RC, Unemo M, et al. Laboratory diagnosis of sexually transmitted infections in Belarus. Acta Derm Venereol. 2011;91(1):64-5. DOI: 10.2340/00015555-0982

[34] Henoh MA, Pershina VP, Lapinskaya EM. Effect of deep freezing on protein solutions. Tsitologiya. 1966;8(6):769-72.

[35] Schellekens H, Casadevall N. Immunogenicity of recombinant human proteins: causes and consequences. J Neurol. 2004;251(2):4-9. DOI: 10.1007/s00415-004-1202-9

[36] MacLennan S, Barbara J. Risks and side effects of therapy with plasma and plasma fractions. Best Pract Res Clin Hematol. 2006;19(1):169-89. DOI: 10.1016/j.beha.2005.01.033

[37] Kostantino GR, Shvenderman SR, Langer R. Damage to preparations of lyophilized protein. Biochemistry (Moscow). 1998;63(3):422-9.

[38] Lock RJ. My approach to internal quality control in a clinical immunology laboratory. J Clin Pathol. 2006;59(7):681-4.

[39] Kanev AN, Vorobeva MS, Shalunova NV. The construction of standard serum panels with a normalized IgG antibody level. Voprosyi Virusologii. 1996;41(4):161-6.

[40] Kanev AN, Shalunova NV, Netesov SV. Designing a reference panel of sera for hepatitis C virus with a normalized level of IgG antibodies. Voprosyi Virusologii. 2000;45(4):42-7.

[41] Lichstein HC, Malcolm HS. Studies of the effect of sodium azide on microbic growth and respiration. $\mathbf{J}$ Bacteriol. 1943;47(3):221-30.

[42] Kurashvili LV, Besedina NF. Evaluation of liquid human serum used to control the quality of clinical and biochemical studies. Clin Lab Diagn. 1995;1:6-8.

[43] Costantino H, Schwenderman S, Griebenov K. The secondary structure and aggregation of lyophilized tetanus toxoid. J Pharm Sci. 1996;85(12):1290-3.

[44] Crotts G, Park T. Stability and relese of bovine serum albumin encapsulated with poly (D,L-lactice-co-glycolide) microparticles. J Control Release. 1997;44(1-2):123-34. DOI: 10.1016/s0168-3659(96)01511-8

[45] Sola-Penna M, Meyer-Fernandes J. Stabilisation ageinst thermal inactivation promoted by sugars on enzyme structure and function: why is trehalose more effective then other sugars. Arch Biochem Biophis. 1998;360(1):10-4. DOI: 10.1006/abbi.1998.0906

[46] Imamura K, Ogawa T, Sakiyama T. Effects of types of sugar on the stabilization of protein in the dried state. J Pharm Sci. 2003;92(2):266-74. DOI: $10.1002 /$ jps. 10305

[47] Brande J, Landkjager L. Chemical stability of insulin. 3. Influence of excipients, formulations, and pH. Acta Pharm Nord. 1992;4(3):149-58.

[48] Hsieh SY, Chen RK, Pan YH. Systematical evaluation of the effects of sample collection procedures on low-molecular-weight serum/plasma proteome profiling. Proteomics. 2006;6(10):189-98. DOI: 10.1002/pmic.200500535

\section{В.М. Щетинін}

\section{СУЧАСНІ ПІДХОДИ ДО ОЦІНКИ ЯКОСТІ ІМУНОФЕРМЕНТНИХ ДІАГНОСТИЧНИХ НАБОРІВ}

Проблематика. Набори для проведення імуноферментної діагностики являють собою медичні вироби, що покликані розв'язувати надзвичайно відповідальну задачу, оскільки від правильності результату лабораторного дослідження залежать здоров'я та життя пацієнта. Тому на сучасному етапі особливу увагу приділяють питанням якості медичних виробів для діагностики in vitro, що пов'язано з питаннями стандартизації та технічного регулювання.

Мета. Аналіз сучасних методологічних підходів до оцінки якості діагностичних наборів на основі імуноферментного аналізу (ІФА). Методика реалізації. Розглянуто і критично проаналізовано результати розробки, стандартизації та тестування діагностичних ІФА-наборів, а також рекомендації міжнародних установ і сертиффікаційних органів.

Результати. Проаналізовано властивості біологічних компонентів діагностичних ІФА-наборів (імуноферментні кон'югати та імуносорбенти) і визначено їх вплив на діагностичні показники аналізу. Розглянуто сучасну методологію оцінки якості імуноферментних кон'югатів та діагностичних наборів у цілому. Продемонстровано важливу роль стандартизованих панелей сироваток (кваліфікаційної, верифікаційної, сероконверсійної, експертної, панелі чутливості) у процедурі оцінки діагностичної якості ІФА-наборів. 
Проаналізовано методи отримання контрольних матеріалів, що використовуються для оцінки якості діагностичних наборів, і приділено особливу увагу прийомам, що забезпечують стабільність сироваткових препаратів.

Висновки. У випадку найбільш соціально важливих інфекцій (ВІЛ, гепатити В та С) регуляторними органами та/або міжнародними інституціями встановлюються найжорсткіші значення показників специфічності та чутливості. У випадку ж інших захворювань нормування діагностичних показників якості має проводитися (обґрунтовуватися) розробником (виробником) індивідуально.

Ключові слова: ІФА-набори; діагностична якість; сироваткові панелі; контрольні матеріали.

\section{В.Н. Щетинин}

\section{СОВРЕМЕННЫЕ ПОДХОДЫ К ОЦЕНКЕ КАЧЕСТВА ИММУНОФЕРМЕНТНЫХ ДИАГНОСТИЧЕСКИХ НАБОРОВ}

Проблематика. Наборы для проведения иммуноферментной диагностики представляют собой медицинские изделия, которые призваны решать чрезвычайно ответственную задачу, поскольку от правильности результата лабораторного исследования зависят здоровье и жизнь пациента. Поэтому на современном этапе особое внимание уделяется вопросам качества медицинских изделий для диагностики in vitro, что связано с вопросами стандартизации и технического регулирования.

Цель. Анализ современных методологических подходов к оценке качества диагностических наборов на основе иммуноферментного анализа (ИФА).

Методика реализации. Рассмотрены и критически проанализированы результаты разработки, стандартизации и тестирования ИФА-наборов, а также рекомендации международных организаций и сертификационных органов.

Результаты. Проанализированы свойства биологических компонентов диагностических ИФА-наборов (иммуноферментные конъюгаты и иммуносорбенты), и определено их влияние на диагностические показатели анализа. Рассмотрена современная методология оценки качества иммуноферментных конъюгатов и диагностических наборов в целом. Продемонстрирована важная роль стандартизированных панелей сывороток (квалификационной, верификационной, сероконверсионной, экспертной, панели чувствительности) в процедуре оценки диагностического качества ИФА-наборов. Проанализированы методы получения контрольных материалов, используемых для оценки качества диагностических наборов, и уделено особое внимание приемам, обеспечивающим стабильность сывороточных препаратов.

Выводы. В случае наиболее социально важных инфекций (ВИЧ, гепатиты В и С) регуляторными органами и/или международными организациями устанавливаются жесточайшие значения показателей специфичности и чувствительности. В случае же других заболеваний нормирование диагностических показателей качества должна проводиться (обосновываться) разработчиком (производителем) индивидуально.

Ключевые слова: ИФА-наборы; диагностическое качество; сывороточные панели; контрольные материалы. 